\title{
1. Introduction: debates over monetary and fiscal policy
}

\section{OBJECTIVES OF THE BOOK}

The 1960s saw the beginning of an intellectual battle between Keynesians and monetarists, exemplified by a series of papers in which the relative potency of fiscal and monetary policy were compared (Friedman and Meiselman, 1963; Ando and Modigliani, 1965). However, it was the 1970s which saw the ideas of monetarism sweep all before it and the decline of Keynesian economics. Monetarism combined a range of features, but there are two which stand out as particularly important and relevant for the discussion and analysis of this book (for a recent review, see Bernanke, 2003c). The first was the doctrine that inflation is always and everywhere a monetary phenomenon' (Friedman, 1960), which had a strong appeal in an era of rising inflation, with the 1960 s and the early 1970 s seeing perhaps the first sustained inflation not associated with war or the aftermath of war. Monetarism advanced the view that a sustained rise in the stock of money (caused by the government or its agencies) led to a rise in the price level. When the supply of money ran ahead of the demand for money, there was 'excess' money, which people spent, thereby bidding up output initially but then, and in a sustained manner, prices. The conclusion for economic policy readily followed: limit the growth of the money supply, and thereby limit the growth of prices, and the rate of inflation. Monetary policy became associated with control of the money supply, and a range of governments, particularly in the early 1980s, announced money supply targets. Monetary policy was assigned the sole role of the control of inflation, and alternative policies, such as incomes policy, for the control of inflation were dismissed.

Second, Friedman (1968) advanced the notion of the 'natural rate of unemployment', as a supply-side equilibrium at which the labour market would clear, where inflation would be constant and towards which the actual level of unemployment would tend rather quickly. The 'natural rate' doctrine ran counter to the prevailing Keynesian perspective in a number of respects. There was the implicit reinstatement of Say's Law whereby there would not be any general deficiency of demand. The supply-side equilibrium in effect ruled the roost: it determined the point towards which the economy would 
quickly gravitate, and the time path of aggregate demand would not affect the equilibrium position. The macroeconomy was viewed as inherently stable and, left to its own devices, it would converge on this equilibrium position.

Monetarism based on those two features did not continue its dominance of economic thinking for long. Control of the money supply proved elusive, with governments and central banks who focused on the growth of the money supply generally failing to hit their targets. Indeed, the demand for money became unstable as a consequence of financial innovations. Poole (1970) had already demonstrated that, when the LM relationship (from the IS-LM approach with the equilibrium condition of demand for money equal to supply of money) was unstable essentially because of money-demand instability (as a result of financial innovation, for example), the rate of interest should be used as the target of monetary policy. The money supply target was quickly abandoned. But still the association between monetary policy and the control of inflation remained. The instrument of monetary policy became the setting of the key interest rate by the central bank. In many respects, the use of interest rates had never been abandoned, but their use was now directed at inflation rather than at achieving some target for the money supply (or indeed any other target such as the exchange rate). Another reason for the abandonment of concentration on money supply was that attempts to control the growth of the money supply had become associated with high and rising unemployment. The notion that the announcement of a money supply target would reduce inflationary expectations and lead to a relatively painless reduction in inflation with little unemployment was quickly dispelled.

The 'natural rate of unemployment' as formulated by Friedman (1968) could be associated with some notion of full employment, that is, Walrasian general equilibrium, and the clearing of the labour market. A more general notion of the non-accelerating inflation rate of unemployment (NAIRU), which does not necessarily embody any notions of full employment, has generally replaced the 'natural rate of unemployment' (in the sense of a clearing labour market involving full employment), although, confusingly, the term 'natural rate of unemployment' is widely used to mean that level of unemployment consistent with constant inflation. But the notion that there is a supply-side equilibrium (which has the desirable property of being associated with a constant rate of inflation), which is unaffected by what happens on the demand side of the economy, has remained a key feature of the "new consensus' in macroeconomics. Further, the idea has also remained that changing this supply-side equilibrium requires changes in the structure and organization of the labour market. In general, the argument has been that making the labour market more 'flexible' (a term with a wide variety of meanings in this context) is required to reduce the (equilibrium) level of unemployment (and thereby reduce the actual level of unemployment). 
The practice of monetary policy has encapsulated these ideas; monetary policy can focus on inflation without having any effect on the supply-side equilibrium. Further, monetary policy can only address inflation since it does not have (by assumption) any sustained impact on level of economic activity or on the rate of economic growth.

The idea of monetary policy focusing on inflation, and inflation alone, can be linked with the shift (starting in New Zealand in 1990) towards the introduction of an 'independent' central bank. In this context, an 'independent' central bank is taken to include the operational independence (from political or democratic involvement) of the central bank, combined with the statement by the government (or by the central bank itself) of the objective to be pursued by the central bank, which has generally been some variant on control of the rate of inflation. In many cases, what has been termed 'inflation targeting' has been adopted under which the central bank is either given a numerical value or range for the rate of inflation (for example, the Bank of Canada is given a specific value; the Bank of England was set a target of 2.5 per cent (with a margin of 1 per cent either side) in terms of the Retail Price Index, recently amended to 2 per cent in terms of the harmonised index of consumer prices (HICP)), or deciding by itself (the European Central Bank's case, for example, where the focus is on price stability defined as 'near to 2 per cent'). ${ }^{1}$ This has gone along with the view that interest rates are raised in the face of inflationary pressures and lowered in the face of deflationary pressures.

The shift to 'independence' of central banks was strongly pushed by some other considerations as well. The idea was developed that central banks with their expertise in monetary policy should be more trusted with decisions over interest rates (and more generally over macroeconomic policy) than elected politicians could be. ${ }^{2}$ This line of argument built upon two separate notions. The first notion came from the idea that there was a trade-off between unemployment and future inflation (in the form of a Phillips curve). It was argued that elected politicians would favour the short-run stimulus of the economy to reduce unemployment, but this would be at the expense of higher future inflation. In contrast, central bankers were deemed 'more conservative' (Rogoff, 1985) and placed more weight on inflation and less on unemployment. Hence central bankers would be less prone than elected politicians to reflate the economy, since central bankers did not face re-election. Second, the central bank was deemed to be more 'credible' (in part reflecting the arguments just given). This enhanced credibility would mean that if, for example, interest rates were cut, this would be interpreted by the financial markets and others to indicate that inflationary pressures were low and the economy could safely be expanded, whereas a similar cut by government might be interpreted to signal the pursuit of low unemployment over low 
inflation. Further, if the commitment of central banks to achieving low inflation was believed, along with its ability to actually achieve it, then expectations of low inflation would be enhanced, and those very expectations would enable the achievement of low inflation. The commitment of the central bank to achieving low inflation could be 'locked in' through the setting of clear objectives for the central bank in terms of an inflation target.

The rise in importance of monetary policy has been accompanied by a downgrading of fiscal policy. The reduced importance of fiscal policy in macroeconomic policy making has at least three dimensions. The first is the virtual ending of the use of fiscal policy to 'fine-tune' the economy. The second is that fiscal policy should be confined to operating as an 'automatic stabilizer', and to do so around an average budget deficit position which was constrained. The third, and most important, is that a high level of employment has largely disappeared as an objective of macroeconomic policy. Insofar as the level of employment is a policy objective, it is to be addressed through 'pricing people back into work', through changes in the unemployment benefit system ('making work pay'), reform of labour laws, trade unions and labour market regulations and so on. Fiscal policy had hitherto been seen as one of the means by which high levels of employment would be achieved. Now fiscal policy and high levels of employment as a macroeconomic objective have been largely off the political agenda.

As the title suggests, this book focuses on monetary and fiscal policies. Much of our discussion of these policies begins from what has been termed the 'new consensus' in macroeconomics (for example, McCallum, 2001; Meyer, 2001a), along with its main policy prescription that has come to be known as 'inflation targeting'. We elaborate on both these aspects in Chapter 2. In Chapter 3 we further elaborate on, and illustrate the nature of, the "new consensus' by referring to a specific macroeconomic model used for policy purposes. This is the macroeconometric model as in Bank of England (1999, 2000). This 'new consensus' reflects a number of the features, which we have outlined above: the emphasis on monetary policy rather than fiscal policy, the essential stability of the market economy and the absence of generalized deficient demand, the key role of a supply-side equilibrium position. We evaluate critically some of the ideas embedded in this 'new consensus'. In view of the central role which has been given to monetary policy in macroeconomic policy measures, it is necessary to enquire as to how monetary policy (in the form of interest rate changes) affects the rate of inflation: is it an effective policy instrument? Further, it is important to enquire as to whether monetary policy has other effects on the economy, on the level of employment and of investment for example. This is undertaken in Chapter 3.

Monetarism was founded on the idea that the stock of money could be treated as under the control of government ('helicopter money', to draw on 
Friedman's, 1969, famous analogy). As such, the stock of money could be seen as causing inflation (or more generally the nominal level of economic activity). It becomes apparent in the discussion of the 'new consensus' that the stock of money makes little or no appearance: money has 'disappeared'. In Chapter 4 we consider the ways in which a number of authors have attempted to reinstate a causal role for money. We argue that none of these has been successful, and that money should be treated as credit money created within the banking system.

Chapter 5 provides further consideration of the effectiveness of monetary policy. When interest rate is used as the monetary policy instrument, then monetary policy is viewed as influencing the level of aggregate demand and, thereby, it is postulated, the rate of inflation. From this perspective, monetary policy can be compared with the alternative means of influencing aggregate demand, namely fiscal policy.

In Chapter 6 we put forward an alternative analysis of the inflationary process and the determination of the level of economic activity to that contained in the new consensus in macroeconomics (NCM). This view comprises four key elements: the level of demand relative to the size of productive capacity; the inherent conflict over the distribution of income; no presumption that the level of demand will generate full employment of labour and/or full capacity utilization; money seen as endogenous credit money created by the banking system.

Although the 'new consensus' has implicitly treated money as created within the banking system (in the jargon, treated money as endogenous), we argue that this 'new consensus' has not fully taken on board the consequences of treating money as endogenous. In Chapter 7 the nature and role of monetary policy when money is treated as endogenous is examined.

The rise of monetary policy has accompanied some demise of fiscal policy, particularly of discretionary fiscal policy. This is perhaps most evident in the convergence criteria of the Maastricht Treaty for a country's membership of the European single currency and in the conditions imposed on member countries by the Stability and Growth Pact. The latter now requires that a national government's budget position be in balance or small surplus over the course of the business cycle and that the deficit never exceeds 3 per cent of GDP. Discretionary fiscal policy is ruled out, but also any fiscal expansion, involving deficit, is regarded as unsustainable. Chapters 8 and 9 examine the case for fiscal policy. Numerous arguments have been advanced to the effect that fiscal policy is ineffective and/or has undesirable effects. We examine critically these arguments and conclude that fiscal policy should be 'reinstated'.

The policy framework for the new European single currency is firmly based on the perspective of the 'new consensus', a case that we establish in 
Chapter 10. Drawing on the previous discussions in the book, it is argued in this chapter that this policy framework will be ineffectual in lowering unemployment or in controlling inflation.

\section{THESIS OF THE BOOK}

We believe this book has managed to put together a consistent thesis, which can be briefly summarized. It has demonstrated the main ingredients of the 'new consensus' in macroeconomics and how monetary policy, as it is currently practised, encapsulates them. The downgrading of fiscal policy has also been highlighted but the book has also argued for its reinstatement. Monetary policy as it is practised these days has been criticized. The economic and monetary union in Europe has been utilized to demonstrate the treatment of both monetary and fiscal policy. This policy framework and its implementation are found unsatisfactory.

There are many implications that can be derived from the analysis in this book. In the rest of this chapter we focus on the particularly important ones. The first implication relates to the role of money and of monetary policy. Inflation will generally cause an increase in the stock of money, but the stock of money itself does not cause inflation. Loans are created by banks within the inflationary process, and those loans create bank deposits and hence the stock of money can expand. How far it expands then depends on what is happening to the demand for money: money only remains in existence if there is someone willing to hold that money. Consequently, seeking to control the growth of the stock of money is fraught with difficulties, as witnessed by the failures of those governments, which sought to control the money supply in the 1980s. It proved particularly difficult to control the stock of money, as would be readily apparent from the realization that the creation of money is in the hands of the banks. If it is profitable for banks to create loans and for bank deposits to increase, then that is likely to happen.

The failure of seeking to control the money supply led to the use of interest rates as the key tool of monetary policy and to the setting of inflation targets to be achieved through monetary policy. The mechanism by which interest rates are meant to influence inflation is via their effects on aggregate demand, and the effect of aggregate demand on the pace of inflation. At best, monetary policy can only address demand inflation, and is unable to do anything about imported inflation or cost inflation. Further, the use of monetary policy in the form of interest rates is likely to have little effect on inflation: simple variation of interest rates has relatively little effect on demand, and demand has little effect on inflation. In Chapters 3 and 4, we summarize some evidence on the effect of interest rates on inflation (from the euro area, the UK and the 
USA) and conclude that it is generally small: in this context small means a one percentage point change in interest rates having an effect of the order of 0.2 to 0.3 per cent on output and rather less on inflation. But further, insofar as interest rates do have an effect, it comes through effects on investment and on the exchange rate. Attempts to counter inflation through raising interest rates have detrimental effects on investment (and thereby on capacity formation) and may tend to raise the exchange rate, thereby harming export prospects. Consequently, our first conclusion is that monetary policy is an ineffective means of controlling inflation. Insofar as it does work, it has detrimental effects on the level of economic activity and on investment and future productive capacity.

The second set of implications arise from the NAIRU type of models, where the adjustment to aggregate demand from within the private sector comes from some form of 'real balance' effect, that is insofar as a rise in prices reduces the real level of aggregate demand. In that case both prices and wages are rising and perhaps real demand is then declining. This could arise if, for example, government expenditure is set in nominal terms. The more usual argument would be that the real balance effect operates through the given nominal money supply. This, however, would not operate in a credit money system. At most the real balance effect could be argued to operate on the narrow definition of money (cash, bank notes and banks' reserves with the central bank). In the UK, this definition is equivalent to a little over 3 per cent of gross domestic product (GDP), and hence a 10 per cent rise in prices would reduce the narrow definition of money (assuming no compensating change in it) in real terms by the equivalent of 0.3 per cent of GDP, and the effect of such a change in real wealth would be very much smaller. Recent estimates reported in OECD (2000) put the marginal propensity to consume out of wealth in the range of 0.02 to 0.05 . It can be concluded that the aggregate demand adjustment from this source would be rather small.

Government policy (including fiscal and, especially, monetary policy) can be a significant agent of adjustment. For example, a monetary policy based on the adjustment of interest rates in response to the inflationary climate can have the effect of moving aggregate demand towards the NAIRU level. In a similar vein, fiscal policy may be used to adjust the level of aggregate demand. The adjustment would not be automatic and would require macroeconomic policy, which responds to changes in the rate of inflation and/or the level of unemployment relative to the NAIRU. Therefore the NAIRU is likely to be a weak attractor for the actual rate of unemployment. The NAIRU is a theoretical construct, which portrays an equilibrium position. Not only does the actual rate of unemployment differ from the NAIRU at any particular point in time but the NAIRU may be a weak (or zero) attractor for the actual rate of unemployment. 
The third set of implications concern the importance of investment, capacity and its distribution. We take the view that the level of employment does not depend on the operations of the labour market, but rather on the level of aggregate demand. In effect there is unemployment not because real wages are too high or the labour market has failed to clear but because the demand for labour is too low, and in turn the demand for labour is too low because the level of aggregate demand is too low. Measures to reduce real wages or to change the workings of the labour market may be counterproductive (if they reduce aggregate demand), but will fail unless aggregate demand is increased. To this insight a further (and rather obvious) one is added, namely that an economy's ability to generate employment depends on the size and distribution of its productive capacity. There is little to reason to think that either aggregate demand or productive capacity will be sufficient to support full employment. We argue (see Chapter 6) that there is some form of an inflation barrier, such that, if the level of economic activity is higher than the barrier, there is a tendency for inflation to increase. But it is important to realize the nature of the barrier: it is perceived to arise from the interaction of the productive capacity of the economy and the claims on income shares.

The fourth set of implications (related to the preceding two) is that deflationary policies designed to reduce inflation will have detrimental effects on the pace of investment, and thereby on the capital stock. As the future productive capacity is thereby lower (than it would have otherwise been), the future inflation problem is made worse.

The fifth implication comes from the contrast between the inflation barrier arising from capacity constraints and the NAIRU as a labour market phenomenon. The latter view suggests that the NAIRU (and the natural rate of unemployment) depend on the characteristics of the labour market: notice the mentions of trade union powers, minimum wages, unemployment benefits and so on. Now it can be observed that those are typically characteristics which apply across the whole of the economy. Laws on trade unions, regulation of labour markets, unemployment benefits and minimum wages are characteristics that apply to the whole economy and do not (in general) vary from area to area. It is, we suggest, implausible to think that the variations in unemployment which are observed between the different regions of a country (or indeed between, say, urban and rural areas, or between ethnic groups), can be explained by variations in the labour market characteristics of the regions involved. It is much more plausible to view the variations in unemployment as arising from the industrial structure of a region and from variations in productive capacity and in the demand for the production of the region.

The sixth, and final, point relates to the focus on the role of the distribution of income. The inflation barrier depends on the extent of the conflict over the distribution of income. Higher claims by enterprises for profits would involve 
lower real wages and lower employment. Higher claims by workers would involve higher real wages but lower employment.

\section{NOTES}

1. Note, though, that although the ECB is 'independent', it does not view itself as pursuing 'inflation targeting' (see discussion in Chapter 10 below).

2. Keynes (1932) was the first to suggest that an 'independent' Bank of England was well equipped, and in a much better position, to conduct monetary policy than otherwise. For further details on Keynes's views on 'independent' central banks, see the recent contribution by Bibow (2002b). 